\title{
Olmesartan/amlodipine/hydrochlorothiazide in participants with hypertension and diabetes, chronic kidney disease, or chronic cardiovascular disease: a subanalysis of the multicenter, randomized, double-blind, parallel-group TRINITY study
}

Dean J Kereiakes ${ }^{1 *}$, Steven G Chrysant ${ }^{2}$, Joseph L Izzo $\mathrm{Jr}^{3}$, Thomas Littlejohn $\mathrm{II}^{4^{\wedge}}$, Michael Melino ${ }^{5}$, James Lee ${ }^{5}$, Victor Fernandez ${ }^{5}$ and Reinilde Heyrman ${ }^{6}$

\begin{abstract}
Background Patients with hypertension and cardiovascular disease (CVD), diabetes, or chronic kidney disease (CKD) usually require two or more antihypertensive agents to achieve blood pressure (BP) goals.

Methods The efficacy/safety of olmesartan (OM) 40 mg, amlodipine besylate (AML) $10 \mathrm{mg}$, and hydrochlorothiazide (HCTZ) 25 mg versus the component dual-combinations (OM 40/AML 10 mg, OM 40/HCTZ 25 mg, and AML 10/HCTZ 25 mg) was evaluated in participants with diabetes, CKD, or chronic CVD in the Triple Therapy with Olmesartan Medoxomil, Amlodipine, and Hydrochlorothiazide in Hypertensive Patients Study (TRINITY). The primary efficacy end point was least squares (LS) mean reduction from baseline in seated diastolic BP (SeDBP) at week 12. Secondary end points included LS mean reduction in SeSBP and proportion of participants achieving BP goal $(<130 / 80 \mathrm{~mm} \mathrm{Hg}$ ) at week 12 (double-blind randomized period), and LS mean reduction in SeBP and BP goal achievement at week 52/early termination (open-label period).
\end{abstract}

Results At week 12, OM 40/AML 10/HCTZ 25 mg resulted in significantly greater SeBP reductions in participants with diabetes (-37.9/22.0 mm Hg vs $-28.0 / 17.6 \mathrm{~mm} \mathrm{Hg}$ for OM 40/AML $10 \mathrm{mg},-26.4 / 14.7 \mathrm{~mm}$ Hg for OM 40/HCTZ $25 \mathrm{mg}$, and $-27.6 / 14.8 \mathrm{~mm} \mathrm{Hg}$ for AML 10/HCTZ $25 \mathrm{mg})$, CKD (-44.3/25.5 mm Hg vs $-39.5 / 23.8 \mathrm{~mm} \mathrm{Hg}$ for OM 40/AML $10 \mathrm{mg},-25.3 / 17.0 \mathrm{~mm} \mathrm{Hg}$ for OM 40/HCTZ $25 \mathrm{mg}$, and -33.4/20.6 mm Hg for AML 10/HCTZ $25 \mathrm{mg}$ ), and chronic CVD (-37.8/20.6 mm Hg vs -31.7/18.2 mm Hg for OM 40/AML 10 mg, -30.9/17.1 mm Hg for OM 40/HCTZ $25 \mathrm{mg}$, and $-27.5 / 16.1 \mathrm{~mm} \mathrm{Hg}$ for AML 10/HCTZ $25 \mathrm{mg}$ ) ( $P<0.05$ for all subgroups vs dual-component treatments). BP goal achievement was greater for participants receiving triple-combination treatment compared with the dual-combination treatments, and was achieved in $41.1 \%, 55.0 \%$, and $38.9 \%$ of participants with diabetes, CKD, and chronic CVD on OM 40/AML 10/HCTZ 25 mg, respectively. At week 52, there was sustained BP lowering with the $\mathrm{OM} / \mathrm{AML} / \mathrm{HCTZ}$ regimen. Overall, the triple combination was well tolerated.

(Continued on next page)

\footnotetext{
* Correspondence: lindner@thechristhospital.com

Deceased

'The Christ Hospital Heart and Vascular Center and The Carl and Edyth Lindner Center for Research and Education at the Christ Hospital Cincinnati, $\mathrm{OH}, \mathrm{USA}$

Full list of author information is available at the end of the article
} 
(Continued from previous page)

Conclusions In patients with diabetes, CKD, or chronic CVD, short-term (12 weeks) and long-term treatment with OM 40/AML 10/HCTZ 25 mg was well tolerated, lowered BP more effectively, and enabled more participants to reach $\mathrm{BP}$ goal than the corresponding 2-component regimens.

Trial Identification Number: NCT00649389

Keywords: Hypertension, Diabetes mellitus, Chronic kidney disease, Cardiovascular diseases, Drug combinations

\section{Background}

Hypertension is an important risk factor for development of cardiovascular disease (CVD) and chronic kidney disease (CKD) [1-3]. According to previous estimates, the National Health and Nutrition Examination Survey (2005-2008) showed that 98 million (21\%) Americans have hypertension (defined as blood pressure [BP] $>140 / 90 \mathrm{~mm} \mathrm{Hg}$ ). According to new estimates, an additional 52 million (11\%) of American adults (for a total of 150 million adults [32\%]) have uncontrolled BP requiring treatment (as defined by the American Heart Association Task Force as BP $>140 / 90$ mm Hg for lowrisk individuals; $>130 / 80 \mathrm{~mm} \mathrm{Hg}$ for Framingham risk score $>10 \%$, CKD, diabetes, and CVD; and $>120 / 80$ for congestive heart failure). Adults with diabetes (50.6 million), CKD (43.7 million), and CVD (43.3 million) have the greatest prevalence of uncontrolled BP [4]. Hypertension is present in nearly $75 \%$ of patients with CVD, including coronary artery disease, stroke, diabetes, CKD, and peripheral artery disease [5-7]; however, it is estimated that only $53 \%$ of patients receiving antihypertensive treatment achieve BP control [7]. By 2030, it is estimated that $40.5 \%$ of the US population will have CVD [8].

The prevalence of hypertension is disproportionately high in patients who have diabetes [9], and individuals who have hypertension are nearly 2.5 times more likely to develop diabetes within 6 years than those without hypertension. Elevated $\mathrm{BP}$ is an important modifiable risk factor in patients with $\mathrm{CKD}$, and $\mathrm{BP}$ reduction has the potential to both reduce cardiovascular death and attenuate progression of kidney disease [10-12]. It is estimated that triplecombination therapy is needed in at least $25 \%$ of all patients with hypertension in order to control BP [13]. Individuals who have hypertension and diabetes, CKD, or CVD are likely to need multiple antihypertensive agents to achieve the lower BP goals recommended in these high-risk populations [5,6]. Furthermore, single-pill combination therapy may result in increased adherence through reduction in pill burden and simplification of the therapeutic regimen [14]. A study including $\sim 85,000$ patients from Kaiser Permanente found that adherence decreased when the number of medications prescribed increased. In this study, antihypertensive medication adherence levels were $77.2 \%, 69.7 \%$, $62.9 \%$, and $55.5 \%$ in patients who received 1-, 2-, 3-, or 4drug regimens, respectively [15].
The triple combination of olmesartan medoxomil (OM) $40 \mathrm{mg}$, amlodipine besylate (AML) $10 \mathrm{mg}$, and hydrochlorothiazide (HCTZ) $25 \mathrm{mg}$ resulted in statistically significantly greater reductions in seated diastolic BP (SeDBP) and seated systolic BP (SeSBP) than the component dualcombination treatments in the Triple Therapy with Olmesartan Medoxomil, Amlodipine, and Hydrochlorothiazide in Hypertensive Patients Study (TRINITY) [16]. During the 40-week open-label extension period of the TRINITY study, continued administration of $\mathrm{OM} / \mathrm{AML} / \mathrm{HCTZ}$ triplecombination regimens demonstrated maintenance of the BP-lowering effects observed in the double-blind period of the study [17]. Furthermore, in the Blood Pressure Control in All Subgroups with Hypertension (BP-CRUSH) study ( $\mathrm{N}=999$ ), the addition of HCTZ to a single-pill combination of AML/OM allowed more patients to achieve SeBP goals [18].

The objective of these subgroup analyses was to compare the triple-combination treatment of OM 40/AML 10/HCTZ $25 \mathrm{mg}$ with the component dual-combination treatments (OM 40/AML $10 \mathrm{mg}$, OM 40/HCTZ 25 mg, and AML 10/ HCTZ $25 \mathrm{mg}$ ) in participants from the TRINITY study who had hypertension and diabetes (prespecified analysis) [19], CKD (prespecified analysis), or chronic CVD (post hoc analysis), and to evaluate the long-term efficacy and safety of $\mathrm{OM} / \mathrm{AML} / \mathrm{HCTZ}$ in these high-risk subgroups.

\section{Methods}

\section{Study population}

Individuals in the TRINITY study (NCT00649389; http:// clinicaltrials.gov/ct2/show/NCT00649389) were aged $\geq 18$ years with a mean SeBP $\geq 140 / 100$ or $\geq 160 / 90$ mm Hg (off antihypertensive medication) [16]. Persons with type 1 or type 2 diabetes controlled on a stable regimen with diet, insulin, or oral antidiabetes medications for $\geq 30$ days and persons with CKD (creatinine clearance $\geq 30 \mathrm{~mL} / \mathrm{min}$ and $\leq 60 \mathrm{~mL} / \mathrm{min}$ ) were eligible for inclusion. Persons with left ventricular hypertrophy, stable angina, peripheral vascular disease, and hypertensive retinopathy were also eligible for inclusion. Exclusion criteria included uncontrolled diabetes (with or without treatment) (ie, HbA1c $>9.0 \%$ ), stage IV CKD (ie, estimated glomerular filtration rate $<30 \mathrm{~mL} / \mathrm{min} /$ $1.73 \mathrm{~m}^{2}$ ), history of a recent stroke or transient ischemic attack, myocardial infarction, percutaneous coronary intervention, coronary artery bypass surgery, and/or unstable 
angina within 6 months of enrollment or New York Heart Association class III or IV congestive heart failure. Persons with secondary hypertension, symptomatic resting bradycardia, heart block greater than first-degree atrioventricular block, and chronic atrial fibrillation or flutter were also excluded. The study was conducted in accordance with the institutional review board committee regulations and the Declaration of Helsinki [20]. All patients provided written informed consent at screening, before undergoing any study procedures.

\section{Study design}

TRINITY was a phase 3, randomized, parallel-group study conducted at 317 clinical sites in the United States and Puerto Rico and consisted of a 12-week double-blind treatment period followed by a 40-week open-label treatment period. Details of the 12-week study design have been published previously [16]; the study design for the 12-week double-blind and open-label treatment periods is summarized in Figure 1. Eligible study participants (stratified by age, race, and diabetes status) were randomized to a regimen that resulted in the 4 treatment groups that received treatment from weeks 4 to 12 (OM 40/AML $10 \mathrm{mg}$ [singlepill combination], OM 40/HCTZ 25 mg [single-pill combination], AML 10/HCTZ 25 mg [not a single-pill combination; given separately], or OM 40/AML 10/HCTZ 25 mg [single-pill OM/HCTZ combination plus AML]). Although stratification for chronic CVD or CKD was not part of the stratification algorithm, there was a balanced distribution of participants within each of the treatment arms for both comorbidities in the total cohort. All participants received dual-combination treatment for 4 weeks, except for a subset of 36 control study participants who received placebo for 2 weeks and were subsequently switched to 1 of the 3 dual-combination treatments from week 2 to week 4 . At week 4, participants were randomly maintained on dualcombination treatment to week 12 or given triple-combination treatment with OM 40/AML 10/HCTZ 25 mg until week 12. Participants completing the 12-week study were then enrolled in a 40-week open-label treatment period. All participants were switched to OM 40/AML 5/HCTZ $12.5 \mathrm{mg}$ (administered as OM 40/AML $5 \mathrm{mg}$ single-pill combination plus HCTZ $12.5 \mathrm{mg}$ ) at the start of the open-label extension period. Participants not achieving BP goal $(<140 / 90$

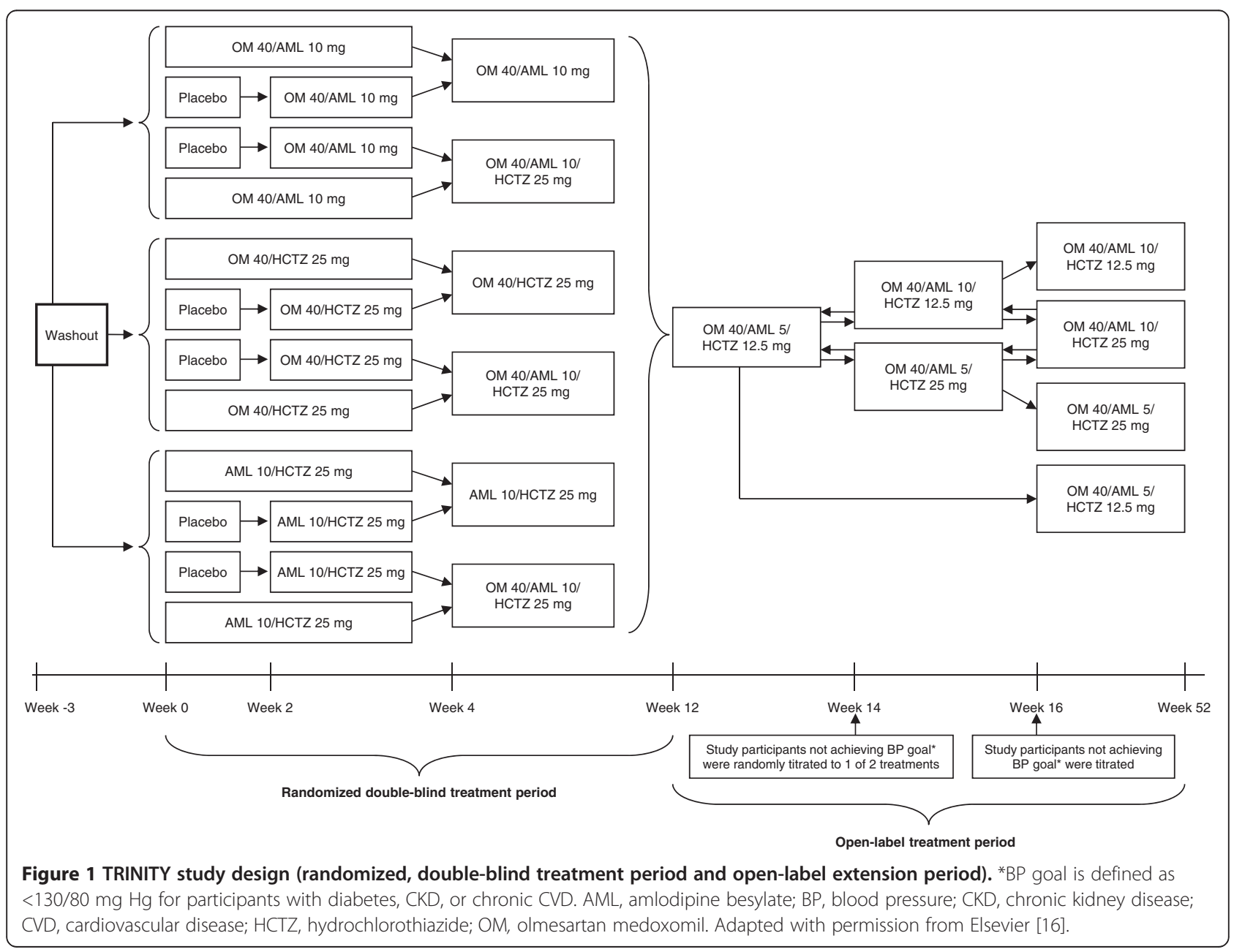


$\mathrm{mm} \mathrm{Hg}$ or $<130 / 80 \mathrm{~mm} \mathrm{Hg}$ for participants with diabetes, CKD, or chronic CVD) after 2 weeks (week 14) were randomly titrated to 1 of 2 treatments (OM 40/AML 10/ HCTZ $12.5 \mathrm{mg}$ [administered as OM 40/AML $10 \mathrm{mg}$ single-pill combination plus HCTZ $12.5 \mathrm{mg}$ ] or OM 40/ AML 5/HCTZ 25 mg [administered as OM 40/AML 5 mg single-pill combination plus HCTZ $25 \mathrm{mg}]$ ). Participants not achieving BP goal 2 weeks after this titration (week 16) were further titrated to OM 40/AML 10/HCTZ $25 \mathrm{mg}$ (administered as OM 40/AML $10 \mathrm{mg}$ single-pill combination plus HCTZ $25 \mathrm{mg}$ ) [17].

\section{Study outcomes}

The primary efficacy end point of the subgroup analyses was the least squares (LS) mean reduction from baseline in SeDBP at week 12 (primary efficacy registration requirement for OM/AML/HCTZ). Secondary end points included LS mean reduction in SeSBP and proportion of participants reaching BP goal $(<130 / 80 \mathrm{~mm} \mathrm{Hg})$ at week 12. For the open-label extension period, efficacy endpoints included mean SeBP and proportion of participants achieving BP goal $(<130 / 80 \mathrm{~mm} \mathrm{Hg})$ at weeks 12, 14, 16, and 52/early termination (ET). Safety assessments included adverse events (AEs), clinical laboratory tests, vital signs, physical examinations, and 12-lead electrocardiograms.

\section{Statistical analysis}

The primary efficacy analysis population was defined as all participants who received at least 1 dose of study medication and had assessments for SeDBP at baseline and at least once post dose. The safety population (for $\mathrm{AE}$ assessment) included all participants receiving at least 1 dose of study medication at or beyond the week 4 visit of the 12-week double-blind period.

For the double-blind treatment period, two-sided $P$ values for testing the significance of the triplecombination treatment versus each dual-combination treatment were derived from an analysis of covariance (ANCOVA) model that had baseline BP as a covariate and fixed effects of final randomized treatment, subgroup (eg, diabetes status subgroup), and final randomized treatment by subgroup interaction. For each comparison, the LS mean difference, corresponding standard error (SE), and two-sided $P$ values were derived from the model. The proportion of participants reaching BP goal in each treatment group was summarized and analyzed using the chi square test. Comparisons between triple-combination treatment and each dualcombination treatment were performed using Fisher's exact test at a 0.05 significance level. The last observation carried forward (LOCF) approach was used for ET measurements during double-blind treatment. Summary statistics by dosing regimen were used to describe SeDBP and SeSBP at each open-label visit week and the proportion of participants reaching BP goal.

\section{Results}

\section{Study participant disposition}

A total of 2492 participants were randomized into the study, of whom 2116 completed the 12-week doubleblind treatment period, 2112 entered the 40-week openlabel extension period ( 4 participants completed the double-blind period of the study, but did not continue in the open-label period: 2 individuals withdrew consent and 2 individuals discontinued from the study due to AEs), and 1796 completed the study (Figure 2). Of the randomized participants, $387(15.5 \%)$ had diabetes, 103 (4.1\%) had CKD, and 227 (9.1\%) had chronic CVD. Participants with comorbid diabetes, CKD, and/or CVD were included in each applicable subgroup. Baseline characteristics of these subgroups are summarized by treatment arm in Table 1. For the diabetes, CKD, and chronic CVD subgroups, mean age was 58.7, 70.1, and 59.6 years and baseline BP was 171.7/98.5, 173.3/96.6, and 173.0/100.4 $\mathrm{mm} \mathrm{Hg}$, respectively.

\section{Efficacy}

\section{Week 12}

In study participants with diabetes, CKD, and chronic CVD, triple-combination treatment with OM 40/AML 10/HCTZ $25 \mathrm{mg}$ resulted in greater BP reductions and a greater proportion of participants achieving BP goal of $<130 / 80 \mathrm{~mm} \mathrm{Hg}$ at week 12 (LOCF) compared with the dual-combination treatments (Figure $3 \mathrm{~A}, 3 \mathrm{~B}$ and $3 \mathrm{C}$ ). Mean SeBP at week 12 was 131.8/77.3, 127.0/72.9, and 132.3/79.9 $\mathrm{mm} \mathrm{Hg}$ for participants with diabetes, CKD, and chronic CVD, respectively. The proportion of participants receiving triple-combination treatment who reached BP goal in each of these subgroups was $41.1 \%$ (diabetes), 55.0\% (CKD), and 38.9\% (chronic CVD).

\section{Week 52}

Mean BP and proportion of participants reaching BP goal $(<130 / 80 \mathrm{~mm} \mathrm{Hg})$ during the open-label extension period in the diabetes, CKD, and chronic CVD subgroups is summarized in Table 2. In the diabetes, CKD, and chronic CVD subgroups, mean SeBP at week 52/ET ranged from 121.4-136.7/74.9-79.7, 118.4-134.0/70.975.0, and 127.1-138.4/77.1-82.3 $\mathrm{mm} \mathrm{Hg}$, respectively. BP goal was reached by an average of $44.3 \%, 51.7 \%$, and $33.7 \%$ of participants with diabetes, CKD, and chronic CVD, respectively.

\section{Safety}

No new safety concerns were identified for either the triple- or dual-combination treatments that were not known to occur with the individual component therapies. 
Treatment-emergent AEs (TEAEs) for the diabetes, CKD, and chronic CVD subgroups during the double-blind treatment period are summarized in Table 3. At week 12, 205 (56.3\%), 56 (57.7\%), and 119 (57.8\%) study participants with diabetes, CKD, and chronic CVD, respectively, had a TEAE. Across all treatment groups for each subgroup, most TEAEs were considered mild or moderate in severity. In total, 11 (3.0\%), 3 (3.1\%), and 6 (2.9\%) participants with diabetes, CKD, and chronic CVD had a serious $\mathrm{AE}$ (SAE) and 11 (3.0\%), 3 (3.1\%), and 6 (2.9\%) discontinued from the study due to a TEAE.

The safety profile for these 3 subgroups during the openlabel treatment period is summarized in Table 4 . The most common TEAEs $(\geq 5 \%)$ across doses during the open-label extension period were upper respiratory tract infection (11; 5.4\%) in participants with diabetes; dizziness (3; 9.4\%), nasopharyngitis $(3 ; 7.7 \%)$, and urinary tract infection (3; 7.7\%) in participants with CKD; and dizziness (6; 6.3\%) and cough $(5 ; 5.3 \%)$ in participants with chronic CVD.
Although small changes were observed in serum chemistry and hematology parameters, there was no apparent relationship to the dose or combination of therapy, and none were considered clinically significant. For the total cohort at week 12/ET, mean glucose levels (non-fasted) were $113.6 \mathrm{mg} / \mathrm{dL}$ (baseline: $108.5 \mathrm{mg} / \mathrm{dL}$ ) for OM 40/AML 10/HCTZ $25 \mathrm{mg} ; 114.1 \mathrm{mg} / \mathrm{dL}$ (baseline: $110.2 \mathrm{mg} / \mathrm{dL}$ ) for OM 40/AML $10 \mathrm{mg} ; 113.3 \mathrm{mg} / \mathrm{dL}$ (baseline: $109.9 \mathrm{mg} / \mathrm{dL}$ ) for OM 40/HCTZ $25 \mathrm{mg}$; and $117.0 \mathrm{mg} / \mathrm{dL}$ (baseline: $107.7 \mathrm{mg} / \mathrm{dL}$ ) for AML 10/HCTZ $25 \mathrm{mg}$. Mean creatinine at week $12 / \mathrm{ET}$ was $0.98 \mathrm{mg} / \mathrm{dL}$ (baseline: $0.92 \mathrm{mg} / \mathrm{dL}$ ) for OM 40/AML 10/HCTZ 25 mg; $0.92 \mathrm{mg} / \mathrm{dL}$ (baseline: $0.95 \mathrm{mg} / \mathrm{dL}$ ) for $\mathrm{OM} \mathrm{40/AML}$ $10 \mathrm{mg} ; 1.0 \mathrm{mg} / \mathrm{dL}$ (baseline: $0.94 \mathrm{mg} / \mathrm{dL}$ ) for $\mathrm{OM} 40 /$ HCTZ $25 \mathrm{mg}$; and $0.94 \mathrm{mg} / \mathrm{dL}$ (baseline: $0.93 \mathrm{mg} / \mathrm{dL}$ ) for AML 10/HCTZ $25 \mathrm{mg}$. Creatinine clearance was $112.5 \mathrm{~mL} / \mathrm{min}$ (baseline: $119.5 \mathrm{~mL} / \mathrm{min}$ ); $121.8 \mathrm{~mL} / \mathrm{min}$ (baseline: $121.8 \mathrm{~mL} / \mathrm{min}$ ); $109.5 \mathrm{~mL} / \mathrm{min}$ (baseline: 117.7 $\mathrm{mL} / \mathrm{min}$ ); and $118.6 \mathrm{~mL} / \mathrm{min}$ (baseline: $120.5 \mathrm{~mL} / \mathrm{min}$ )

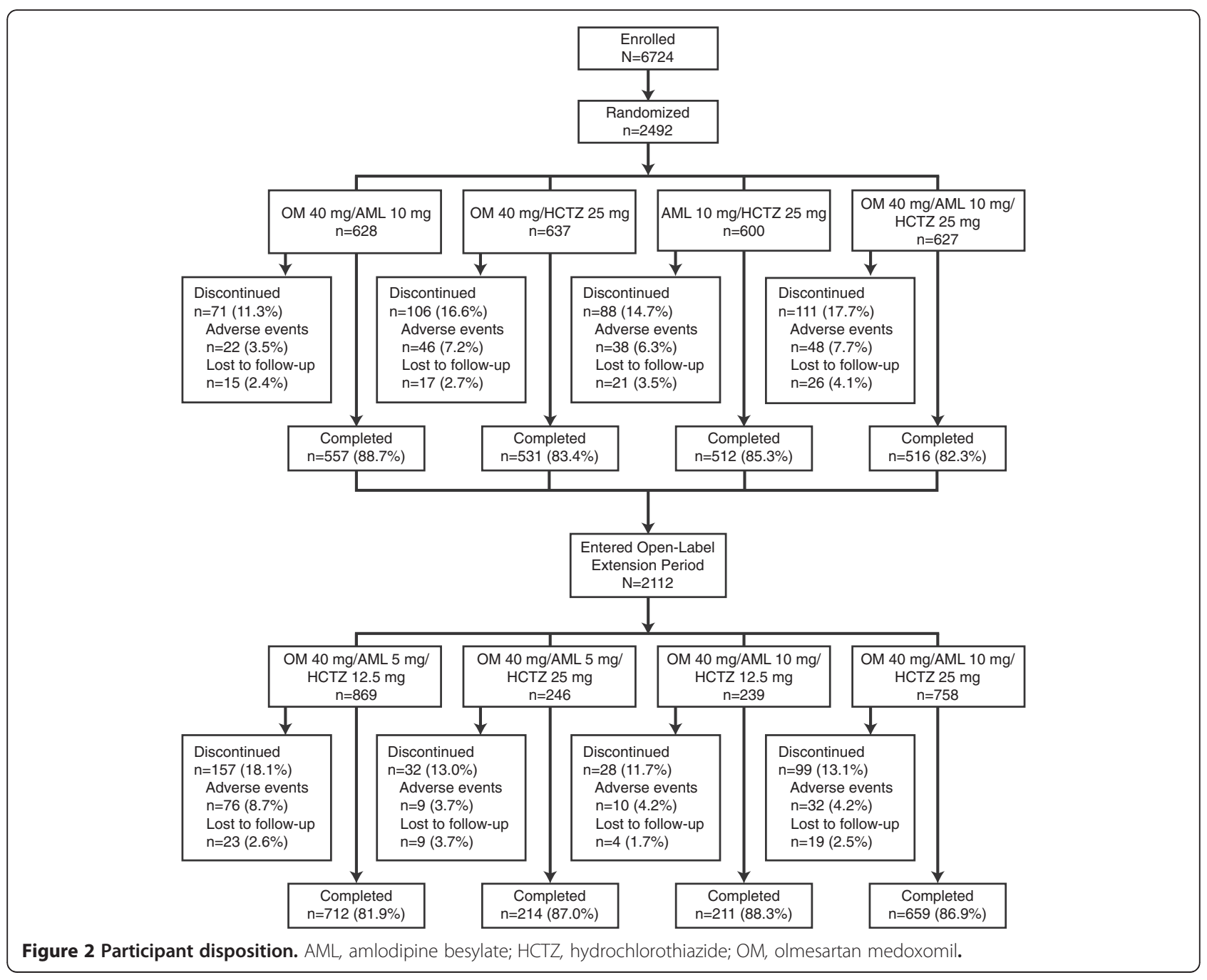


Table 1 Demographic and baseline characteristics of the diabetes, CKD, and chronic CVD subgroups (randomized set)

\begin{tabular}{|c|c|c|c|c|c|c|c|c|c|c|c|c|}
\hline & \multicolumn{4}{|c|}{ Diabetes $(n=387)$} & \multicolumn{4}{|c|}{ CKD $(n=103)$} & \multicolumn{4}{|c|}{ Chronic CVD ( $n=227)$} \\
\hline & $\begin{array}{l}\text { OM 40/ } \\
\text { AML } \\
10 \mathrm{mg}\end{array}$ & $\begin{array}{l}\text { OM 40/ } \\
\text { HCTZ } \\
25 \mathrm{mg}\end{array}$ & $\begin{array}{l}\text { AML 10/ } \\
\text { HCTZ } \\
25 \mathrm{mg}\end{array}$ & $\begin{array}{c}\text { OM 40/ AML 10/ } \\
\text { HCTZ } \\
25 \mathrm{mg}\end{array}$ & $\begin{array}{c}\text { OM 40/ } \\
\text { AML } \\
10 \mathrm{mg}\end{array}$ & $\begin{array}{l}\text { OM 40/ } \\
\text { HCTZ } \\
25 \mathrm{mg}\end{array}$ & $\begin{array}{l}\text { AML 10/ } \\
\text { HCTZ } \\
25 \mathrm{mg}\end{array}$ & $\begin{array}{c}\text { OM 40/ AML 10/ } \\
\text { HCTZ } \\
25 \mathrm{mg}\end{array}$ & $\begin{array}{c}\text { OM 40/ } \\
\text { AML } \\
10 \mathrm{mg}\end{array}$ & $\begin{array}{l}\text { OM 40/ } \\
\text { HCTZ } \\
25 \mathrm{mg}\end{array}$ & $\begin{array}{l}\text { AML 10/ } \\
\text { HCTZ } \\
25 \mathrm{mg}\end{array}$ & $\begin{array}{c}\text { OM 40/ AML 10/ } \\
\text { HCTZ } \\
25 \mathrm{mg}\end{array}$ \\
\hline & $(n=100)$ & $(n=99)$ & $(n=92)$ & $(n=96)$ & $(n=29)$ & $(n=25)$ & $(n=29)$ & $(n=20)$ & $(n=56)$ & $(n=61)$ & $(n=55)$ & $(n=55)$ \\
\hline Age, mean (SD), yrs & $59.7(8.9)$ & $60.3(8.7)$ & $56.5(9.4)$ & $58.1(9.4)$ & $71.0(7.8)$ & $71.5(9.4)$ & $69.4(9.5)$ & $68.1(10.0)$ & $60.2(11.2)$ & $61.1(9.8)$ & $58.2(11.0)$ & $58.6(10.9)$ \\
\hline Male, n (\%) & $60(60.0)$ & $54(54.5)$ & $52(56.5)$ & $51(53.1)$ & $9(31.0)$ & $10(40.0)$ & $10(34.5)$ & $5(25.0)$ & $40(71.4)$ & $38(62.3)$ & $34(61.8)$ & $39(70.9)$ \\
\hline \multicolumn{13}{|l|}{ Ethnicity } \\
\hline Hispanic/Latino, n (\%) & $21(21.0)$ & 18 (18.2) & $13(14.1)$ & $15(15.6)$ & $1(3.4)$ & $2(8.0)$ & $3(10.3)$ & $2(10.0)$ & $8(14.3)$ & $5(8.2)$ & $7(12.7)$ & $8(14.5)$ \\
\hline \multicolumn{13}{|l|}{ Race } \\
\hline White, n (\%) & $72(72.0)$ & $73(73.7)$ & $58(63.0)$ & $67(69.8)$ & $18(62.1)$ & $19(76.0)$ & $21(72.4)$ & $13(65.0)$ & $40(71.4)$ & $45(73.8)$ & $37(67.3)$ & 35 (63.6) \\
\hline Black, n (\%) & $26(26.0)$ & $24(24.2)$ & $29(31.5)$ & $25(26.0)$ & $9(31.0)$ & $5(20.0)$ & $7(24.1)$ & $6(30.0)$ & $16(28.6)$ & $16(26.2)$ & $18(32.7)$ & $17(30.9)$ \\
\hline Obesity, n (\%)* & $77(77.0)$ & $74(74.7)$ & $71(77.2)$ & $73(76.0)$ & $9(31.0)$ & $2(8.0)$ & $7(24.1)$ & $6(30.0)$ & $32(57.1)$ & $40(65.6)$ & 35 (63.6) & $33(60.0)$ \\
\hline $\begin{array}{l}\text { Hypertension duration, } \\
\text { mean }(S D), y\end{array}$ & $12.8(9.6)$ & $13.2(10.5)$ & $11.2(9.6)$ & $10.7(9.8)$ & $12.1(8.0)$ & $14.0(10.0)$ & $13.0(9.3)$ & $14.8(14.4)$ & $12.0(8.0)$ & $15.0(12.3)$ & $12.9(9.9)$ & $13.3(11.0)$ \\
\hline Baseline BP, mean (SD), mm Hg & $\begin{array}{c}172.2 / 98.6 \\
(13.5 / 7.5)\end{array}$ & $\begin{array}{l}173.1 / 97.8 \\
(14.7 / 7.6)\end{array}$ & $\begin{array}{c}170.7 / 99.3 \\
(13.6 / 6.7)\end{array}$ & $\begin{array}{c}170.7 / 98.3 \\
(16.0 / 6.9)\end{array}$ & $\begin{array}{c}174.4 / 96.4 \\
(12.5 / 8.8)\end{array}$ & $\begin{array}{c}172.2 / 96.0 \\
(11.6 / 7.6)\end{array}$ & $\begin{array}{l}172.9 / 97.4 \\
(17.1 / 6.6)\end{array}$ & $\begin{array}{l}173.8 / 96.6 \\
(16.5 / 6.5)\end{array}$ & $\begin{array}{l}173.4 / 101.0 \\
(16.2 / 10.6)\end{array}$ & $\begin{array}{c}172.8 / 99.3 \\
(11.7 / 9.3)\end{array}$ & $\begin{array}{c}174.2 / 100.8 \\
(16.7 / 7.1)\end{array}$ & $\begin{array}{c}171.7 / 100.4 \\
(11.0 / 9.1)\end{array}$ \\
\hline
\end{tabular}

${ }^{*} \mathrm{BMI} \geq 30 \mathrm{~kg} / \mathrm{m}^{2}$.

$A M L$, amlodipine; $B M I$, body mass index; CKD, chronic kidney disease; $C V D$, cardiovascular disease; $H C T Z$, hydrochlorothiazide; OM, olmesartan medoxomil; $S D$, standard deviation. 


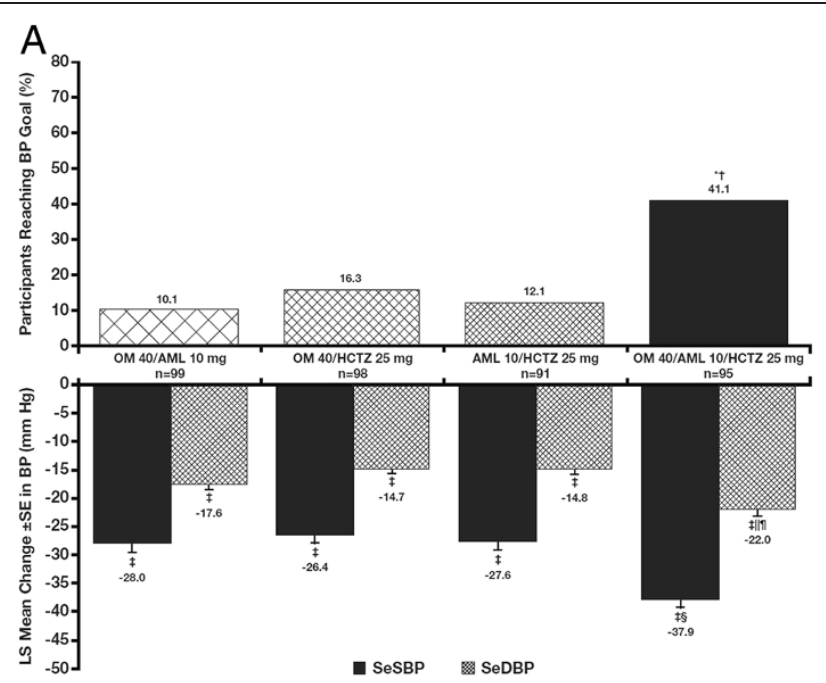

" $P<0.0001$ vs OM 40/AML $10 \mathrm{mg}$ and AML 10/HCTZ $25 \mathrm{mg}$; $P=0.0002$ vs OM 40/HCTZ $25 \mathrm{mg} ;: P_{<} 0.0001$ vs baseline; ${ }_{?}^{5} P<0.0001$ vs each dual-combination treatment; $P<<0.0001$ vs OM $40 / \mathrm{HCTZ} 25 \mathrm{mg}$ and AML $10 / \mathrm{HCTZ} 25 \mathrm{mg}$;
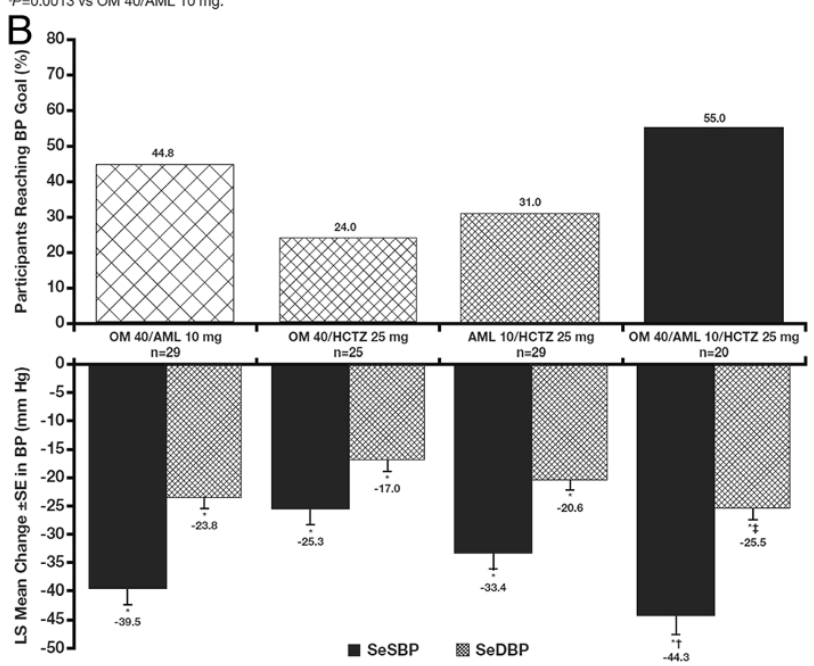

'P $P<0.0001$ vs baseline; ${ }^{\prime} P \leq 0.0141$ vs OM 40/HCTZ $25 \mathrm{mg}$ and AML $10 / \mathrm{HCTZ} 25 \mathrm{mg}$; $: P=0.0023$ vs OM 40/HCTZ $25 \mathrm{mg}$.
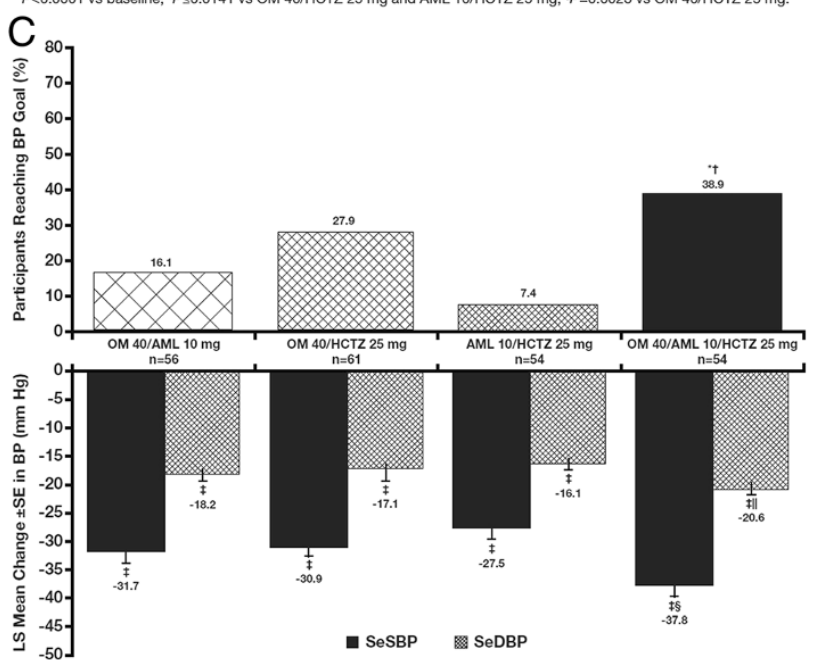

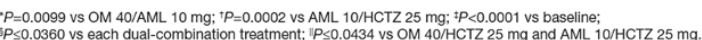

Figure 3 (See legend on next page.) 
(See figure on previous page.)

Figure 3 Diabetes (A), CKD (B), and chronic CVD (C) subgroups: LS Mean (SE) reductions in SeBP and proportion of participants reaching BP goal (<130/80 mm Hg) at week 12 (LOCF). Specific $P$ values are found beneath each panel. AML, amlodipine besylate; BP, blood pressure; CKD, chronic kidney disease; CVD, cardiovascular disease; HCTZ, hydrochlorothiazide; LOCF, last observation carried forward; LS, least squares; OM, olmesartan

medoxomil; SE, standard error.

for the respective treatment groups. No effects on heart rate, electrocardiograms, or physical examinations were observed during the treatment period of the study.

\section{Discussion}

The current subgroup analyses demonstrated the effectiveness of triple-combination treatment in difficultto-treat participants with hypertension and diabetes, CKD, or chronic CVD. BP reductions with triple-combination treatment in these subgroups at week 12 were comparable to those for the overall study cohort $(-37 / 22 \mathrm{~mm} \mathrm{Hg})$ [16]. Long-term treatment with varying doses of $\mathrm{OM} /$ AML/HCTZ in these subgroups resulted in similar BP-lowering effects for those receiving triple-combination treatment during the double-blind period of the study. Triple-combination treatment also enabled these high-risk subgroups to achieve BP goal $(<130 / 80 \mathrm{~mm} \mathrm{Hg})$ at week 12 and at week 52. Triple-combination treatment was well tolerated in these subgroups, with a low percentage of participants discontinuing treatment across treatment groups and no clinically meaningful differences in AEs. The presence of diabetes, CKD, or chronic CVD did not change the AE profile of the drugs used in this analysis from that observed in the total TRINITY study cohort [16].

It has been estimated that at least $75 \%$ of patients with hypertension require combination therapy to maintain BP control [14], and large clinical trials have reported that $23-54 \%$ of participants require 3 or more antihypertensive agents [21-24]. Thus, there is a growing emphasis on the need for practical strategies to consistently achieve and maintain BP goals with the use of multiple antihypertensive agents in clinical practice [14].

Single-pill combination therapy may improve BP control through regimen simplification, which may lead to an improvement in patient adherence, reduction in physician visits, and attainment of BP goals [14,16,25-30]. Single-pill combinations have the potential to increase adherence to therapy compared with free-dose combinations [31,32], particularly in patients with hypertension and cardiovascular comorbidities. Such patients are at increased risk of nonadherence due to the need for multiple medications

Table 2 Mean BP and proportion of participants reaching BP goal (<130/80 mm Hg) at weeks 12 and 52/ET

\begin{tabular}{llll}
\hline Time point & Diabetes & CKD & Chronic CVD \\
\hline Week 12 & 333 & 93 & 191 \\
$\mathbf{n}$ & $138.9 / 81.2(17.4 / 9.6)$ & $135.0 / 76.5(20.6 / 10.9)$ & $137.7 / 81.4(15.7 / 10.3)$ \\
OM 40/AML 5/HCTZ 12.5 mg* & 22 & 40 & 25 \\
\% to goal & & & 56 \\
Week 52/ET & 62 & 29 & $127.1 / 77.1(18.8 / 12.4)$ \\
$\mathbf{n}$ & $121.4 / 74.9(14.5 / 8.8)$ & $118.4 / 70.9(12.6 / 7.9)$ & 54 \\
OM 40/AML 5/HCTZ 12.5 mg & 65 & 79 & 29 \\
\% to goal & 34 & 13 & $134.2 / 78.0(17.0 / 11.6)$ \\
n & $129.5 / 77.2(15.6 / 9.9)$ & $126.5 / 72.4(22.5 / 10.5)$ & 35 \\
OM 40/AML 5/HCTZ 25 mg & 38 & 54 & 20 \\
\% to goal & 40 & 14 & $132.9 / 77.6(11.1 / 8.5)$ \\
n & $128.8 / 77.0(11.6 / 8.5)$ & $122.3 / 70.9(15.6 / 8.1)$ & 20 \\
OM 40/AML 10/HCTZ 12.5 mg & 50 & 43 & 86 \\
\% to goal & 197 & 36 & $138.4 / 82.3(16.2 / 10.6)$ \\
n & $136.7 / 79.7(15.2 / 9.7)$ & $134.0 / 75.0(17.7 / 10.3)$ & 27 \\
OM 40/AML 10/HCTZ 25 mg & 24 & 31 & \\
\% to goal & & & \\
\hline
\end{tabular}

BP data are mean (SD), $\mathrm{mm} \mathrm{Hg}$.

*Week 12 data are from the end of the double-blind treatment period before all participants were switched to OM 40/AML 5/HCTZ 12.5 mg at the beginning of the open-label extension period.

$A M L$, amlodipine; $B P$, blood pressure; $C K D$, chronic kidney disease; $C V D$, cardiovascular disease; $E T$, early termination; $H C T Z$, hydrochlorothiazide; $O M$, olmesartan medoxomil; $S D$, standard deviation. 
Table 3 Study participants with treatment-emergent adverse events at week 12

\begin{tabular}{|c|c|c|c|c|c|c|c|c|c|c|c|c|}
\hline \multirow{3}{*}{ All data n (\%) } & \multicolumn{4}{|c|}{ Diabetes } & \multicolumn{4}{|c|}{ CKD } & \multicolumn{4}{|c|}{ Chronic CVD } \\
\hline & $\begin{array}{c}\text { OM } 40 / \\
\text { AML } \\
10 \mathrm{mg}\end{array}$ & $\begin{array}{c}\text { OM 40/ } \\
\text { HCTZ } \\
25 \mathrm{mg}\end{array}$ & $\begin{array}{c}\text { AML 10/ } \\
\text { HCTZ } \\
25 \mathrm{mg}\end{array}$ & $\begin{array}{c}\text { OM 40/ AML 10/ } \\
\text { HCTZ } \\
25 \mathrm{mg}\end{array}$ & $\begin{array}{l}\text { OM 40/ } \\
\text { AML } \\
10 \mathrm{mg}\end{array}$ & $\begin{array}{l}\text { OM 40/ } \\
\text { HCTZ } \\
25 \mathrm{mg}\end{array}$ & $\begin{array}{l}\text { AML 10/ } \\
\text { HCTZ } \\
25 \mathrm{mg}\end{array}$ & $\begin{array}{c}\text { OM 40/ AML 10/ } \\
\text { HCTZ } \\
25 \mathrm{mg}\end{array}$ & $\begin{array}{c}\text { OM 40/ } \\
\text { AML } \\
10 \mathrm{mg}\end{array}$ & $\begin{array}{l}\text { OM 40/ } \\
\text { HCTZ } \\
25 \mathrm{mg}\end{array}$ & $\begin{array}{l}\text { AML 10/ } \\
\text { HCTZ } \\
25 \mathrm{mg}\end{array}$ & $\begin{array}{c}\text { OM 40/ AML 10/ } \\
\text { HCTZ } \\
25 \mathrm{mg}\end{array}$ \\
\hline & $(n=96)$ & $(n=91)$ & $(n=85)$ & $(n=92)$ & $(n=29)$ & $(n=22)$ & $(n=28)$ & $(n=18)$ & $(n=53)$ & $(n=54)$ & $(n=50)$ & $(n=49)$ \\
\hline All TEAEs* & $47(49.0)$ & $49(53.8)$ & $51(60.0)$ & $58(63.0)$ & $16(55.2)$ & $11(50.0)$ & $20(71.4)$ & $9(50.0)$ & $23(43.4)$ & $32(59.3)$ & $30(60.0)$ & $34(69.4)$ \\
\hline Severe TEAEs & $4(4.2)$ & $4(4.4)$ & $5(5.9)$ & $6(6.5)$ & 0 & $2(9.1)$ & $2(7.1)$ & $1(5.6)$ & $2(3.8)$ & $2(3.7)$ & $2(4.0)$ & $5(10.2)$ \\
\hline Drug-related TEAEs ${ }^{\dagger}$ & $21(21.9)$ & $16(17.6)$ & $17(20.0)$ & $25(27.2)$ & $5(17.2)$ & $8(36.4)$ & $10(35.7)$ & $3(16.7)$ & $9(17.0)$ & $11(20.4)$ & $13(26.0)$ & $17(34.7)$ \\
\hline \multicolumn{13}{|l|}{ Discontinuations } \\
\hline TEAEs & $2(2.1)$ & $2(2.2)$ & $2(2.4)$ & $5(5.4)$ & 0 & $1(4.5)$ & $2(7.1)$ & 0 & 0 & $3(5.6)$ & 0 & $3(6.1)$ \\
\hline Drug-related TEAEs ${ }^{\dagger}$ & $1(1.0)$ & 0 & 0 & $5(5.4)$ & 0 & 0 & $1(3.6)$ & 0 & 0 & 0 & 0 & $2(4.1)$ \\
\hline \multicolumn{13}{|c|}{ TEAEs (>5\% in any treatment group) ${ }^{\ddagger}$} \\
\hline Dizziness & $3(3.1)$ & $3(3.3)$ & $3(3.5)$ & $7(7.6)$ & $1(3.4)$ & $1(4.5)$ & $3(10.7)$ & $1(5.6)$ & $1(1.9)$ & $5(9.3)$ & $2(4.0)$ & $7(14.3)$ \\
\hline Headache & $5(5.2)$ & $8(8.8)$ & $2(2.4)$ & $5(5.4)$ & $1(3.4)$ & $3(13.6)$ & $1(3.6)$ & 0 & $1(1.9)$ & $3(5.6)$ & $1(2.0)$ & $2(4.1)$ \\
\hline Urinary tract infection & $3(3.1)$ & $3(3.3)$ & $3(3.5)$ & $6(6.5)$ & 0 & 0 & 0 & $3(16.7)$ & 0 & 0 & $1(2.0)$ & $2(4.1)$ \\
\hline Upper respiratory tract infection & $2(2.1)$ & $2(2.2)$ & $2(2.4)$ & $2(2.2)$ & $3(10.3)$ & 0 & $1(3.6)$ & $2(11.1)$ & 0 & 0 & $1(2.0)$ & 0 \\
\hline Bronchitis & $2(2.1)$ & 0 & $1(1.2)$ & $3(3.3)$ & 0 & $1(4.5)$ & 0 & $2(11.1)$ & 0 & $3(5.6)$ & $2(4.0)$ & $1(2.0)$ \\
\hline Edema, peripheral & $9(9.4)$ & $1(1.1)$ & $4(4.7)$ & $9(9.8)$ & $1(3.4)$ & $1(4.5)$ & $5(17.9)$ & $1(5.6)$ & $3(5.7)$ & $1(1.9)$ & $4(8.0)$ & $4(8.2)$ \\
\hline Fatigue & $5(5.2)$ & $10(11.0)$ & $6(7.1)$ & $2(2.2)$ & 0 & $1(4.5)$ & $2(7.1)$ & 0 & $2(3.8)$ & $5(9.3)$ & $1(2.0)$ & $3(6.1)$ \\
\hline Joint swelling & $1(1.0)$ & 0 & $2(2.4)$ & $1(1.1)$ & $4(13.8)$ & 0 & 0 & $1(5.6)$ & $1(1.9)$ & $1(1.9)$ & $3(6.0)$ & $3(6.1)$ \\
\hline Muscle spasms & $4(4.2)$ & $2(2.2)$ & 0 & $3(3.3)$ & $1(3.4)$ & $2(9.1)$ & 0 & 0 & 0 & $3(5.6)$ & $3(6.0)$ & 0 \\
\hline Nausea & 0 & $3(3.3)$ & $2(2.4)$ & $4(4.3)$ & $1(3.4)$ & 0 & $2(7.1)$ & 0 & 0 & $2(3.7)$ & 0 & $4(8.2)$ \\
\hline Diarrhea & $1(1.0)$ & $2(2.2)$ & $2(2.4)$ & $2(2.2)$ & $4(13.8)$ & 0 & $1(3.6)$ & 0 & $2(3.8)$ & 0 & $1(2.0)$ & 0 \\
\hline Constipation & 0 & 0 & 0 & $5(5.4)$ & 0 & $1(4.5)$ & $1(3.6)$ & 0 & $1(1.9)$ & 0 & 0 & $2(4.1)$ \\
\hline Hypokalemia & 0 & 0 & $2(2.4)$ & $1(1.1)$ & 0 & 0 & $4(14.3)$ & 0 & 0 & $2(3.7)$ & $3(6.0)$ & 0 \\
\hline
\end{tabular}


Table 4 Study participants with adverse events during the open-label treatment period by onset dosing regimen

\begin{tabular}{|c|c|c|c|c|c|c|c|c|c|c|c|c|}
\hline \multirow{3}{*}{ All data n (\%) } & \multicolumn{4}{|c|}{ Diabetes } & \multicolumn{4}{|c|}{ CKD } & \multicolumn{4}{|c|}{ Chronic CVD } \\
\hline & $\begin{array}{c}\text { OM 40/ } \\
\text { AML 5/ } \\
\text { HCTZ } 12.5 \mathrm{mg}\end{array}$ & $\begin{array}{c}\text { OM 40/ } \\
\text { AML 5/ } \\
\text { ICTZ } 25 \mathrm{mg}\end{array}$ & $\begin{array}{c}\text { OM 40/ } \\
\text { AML 10/ } \\
\text { HCTZ } 12.5 \mathrm{mg}\end{array}$ & $\begin{array}{c}\text { OM 40/ } \\
\text { AML 10/ } \\
\text { HCTZ } 25 \mathrm{mg}\end{array}$ & $\begin{array}{c}\text { OM 40/ } \\
\text { AML 5/ } \\
\text { HCTZ 12.5 }\end{array}$ & $\begin{array}{c}\text { OM 40/ } \\
\text { AML 5/ } \\
\text { HCTZ } 25 \text { mg }\end{array}$ & $\begin{array}{c}\text { OM 40/ } \\
\text { AML 10/ } \\
\text { HCTZ } 12.5 \mathrm{mg}\end{array}$ & $\begin{array}{c}\text { OM 40/ } \\
\text { AML 10/ } \\
\text { HCTZ } 25 \mathrm{mg}\end{array}$ & $\begin{array}{c}\text { OM 40/ } \\
\text { AML 5/ } \\
\text { HCTZ 12.5 }\end{array}$ & $\begin{array}{c}\text { OM 40/ } \\
\text { AML 5/ } \\
\text { HCTZ } 25 \mathrm{mg}\end{array}$ & $\begin{array}{c}\text { OM 40/ } \\
\text { AML 10/ } \\
\text { HCTZ } 12.5 \mathrm{mg}\end{array}$ & $\begin{array}{c}\text { OM 40/ } \\
\text { AML 10/ } \\
\text { HCTZ } 25 \mathrm{mg}\end{array}$ \\
\hline & $(n=334)$ & $(n=139)$ & $(n=143)$ & $(n=203)$ & $(n=93)$ & $(n=35)$ & $(n=32)$ & $(n=39)$ & $(n=191)$ & $(n=74)$ & $(n=70)$ & $(n=95)$ \\
\hline All AEs* & 135 (40.4) & $40(28.8)$ & 48 (33.6) & $120(59.1)$ & $43(46.2)$ & $13(37.1)$ & $15(46.9)$ & $23(59.0)$ & $88(46.1)$ & $25(33.8)$ & $20(28.6)$ & $54(56.8)$ \\
\hline Severe AEs & $12(3.6)$ & $2(1.4)$ & $4(2.8)$ & $8(3.9)$ & $4(4.3)$ & $1(2.9)$ & $1(3.1)$ & $4(10.3)$ & $7(3.7)$ & $1(1.4)$ & $3(4.3)$ & $5(5.3)$ \\
\hline Drug-related $\mathrm{AEs}^{\dagger}$ & $37(11.1)$ & $9(6.5)$ & $12(8.4)$ & $28(13.8)$ & $14(15.1)$ & $4(11.4)$ & $5(15.6)$ & $8(20.5)$ & $30(15.7)$ & $8(10.8)$ & $4(5.7)$ & $24(25.3)$ \\
\hline \multicolumn{13}{|l|}{ Discontinuations } \\
\hline AEs & $5(1.5)$ & $2(1.4)$ & $1(0.7)$ & $9(4.4)$ & $8(8.6)$ & $1(2.9)$ & $2(6.3)$ & $3(7.7)$ & $9(4.7)$ & $1(1.4)$ & 0 & $6(6.3)$ \\
\hline $\begin{array}{l}\text { AEs starting in open- } \\
\text { label extension period }\end{array}$ & $5(1.5)$ & $2(1.4)$ & $1(0.7)$ & $8(3.9)$ & $7(7.5)$ & $1(2.9)$ & $2(6.3)$ & $3(7.7)$ & $9(4.7)$ & $1(1.4)$ & 0 & $6(6.3)$ \\
\hline Drug-related $\mathrm{AEs}^{\dagger}$ & $3(0.9)$ & $2(1.4)$ & $1(0.7)$ & $3(1.5)$ & $6(6.5)$ & 0 & $2(6.3)$ & $2(5.1)$ & $6(3.1)$ & 0 & 0 & $3(3.2)$ \\
\hline \multicolumn{13}{|l|}{$\begin{array}{l}\text { AEs ( }>5 \% \text { in any } \\
{\text { treatment group })^{\ddagger}}^{\text {a }}\end{array}$} \\
\hline Dizziness & $10(3.0)$ & $4(2.9)$ & $3(2.1)$ & $10(4.9)$ & $6(6.5)$ & 0 & $3(9.4)$ & $2(5.1)$ & $7(3.7)$ & 0 & $2(2.9)$ & $6(6.3)$ \\
\hline Urinary tract infection & $13(3.9)$ & $4(2.9)$ & $2(1.4)$ & $9(4.4)$ & $1(1.1)$ & $1(2.9)$ & 0 & $3(7.7)$ & $4(2.1)$ & 0 & $1(1.4)$ & $3(3.2)$ \\
\hline $\begin{array}{l}\text { Upper respiratory tract } \\
\text { infection }\end{array}$ & $8(2.4)$ & 0 & $6(4.2)$ & $11(5.4)$ & $5(5.4)$ & 0 & $2(6.3)$ & $2(5.1)$ & $3(1.6)$ & $1(1.4)$ & $3(4.3)$ & $3(3.2)$ \\
\hline Nasopharyngitis & $2(0.6)$ & $3(2.2)$ & $2(1.4)$ & $8(3.9)$ & $2(2.2)$ & $1(2.9)$ & $1(3.1)$ & $3(7.7)$ & $6(3.1)$ & $1(1.4)$ & 0 & $3(3.2)$ \\
\hline Cough & $6(1.8)$ & $4(2.9)$ & $3(2.1)$ & $4(2.0)$ & $1(1.1)$ & $1(2.9)$ & $2(6.3)$ & $2(5.1)$ & 0 & $1(1.4)$ & $2(2.9)$ & $5(5.3)$ \\
\hline
\end{tabular}

*Adverse events starting before the open-label extension period and not resolved by week 12 were counted under the final dosing regimen

${ }^{\dagger}$ Drug-related was defined as definitely, probably, or possibly related to randomized study medication.

${ }^{\ddagger} \mathrm{AEs}$ presented occurred in $>5 \%$ and at least 3 study participants in any treatment group. Although a participant may have had 2 or more AEs, the participant is counted only once within a category. The same participant may appear in different categories.

$A M L$, amlodipine besylate; CVD, cardiovascular disease; CKD, chronic kidney disease; HCTZ, hydrochlorothiazide; OM, olmesartan medoxomil; TEAE, treatment-emergent adverse event. 
for a variety of comorbidities (eg, dyslipidemia, diabetes) in addition to antihypertensive medications [33,34].

Combining antihypertensive agents from different classes has been estimated to produce BP reductions approximately 5 times greater than doubling the dose of any single agent [35]. A meta-analysis has shown that one drug at standard dose compared with a combination of 3 drugs at half the standard dose reduced the incidence of coronary heart disease by about $24 \%$ and $45 \%$, respectively, and stroke by $33 \%$ and $60 \%$, respectively, in individuals aged 60 to 69 years with SeBP of 150/90 mm Hg [36]. The complementary mechanisms of action of an angiotensin receptor blocker, calcium channel blocker, and diuretic result in each agent targeting a separate pathway and provide coverage for multiple different pathways contributing to hypertension [14,25,35]. Additionally, in patients with evidence of renal disease or at greater risk of developing renal disease, such as those with diabetes mellitus, it is recommended to use reninangiotensin-aldosterone system blocker-based combination therapy $[37,38]$.

Guidelines recognize that multiple antihypertensive agents are often required in patients with diabetes and CKD [5]. In addition, the American Heart Association recommends starting with $\geq 2$ antihypertensive agents in patients with coronary artery disease [6]. The Seventh Report of the Joint National Committee on Prevention, Detection, Evaluation, and Treatment of High Blood Pressure (JNC 7) recommends a lower BP goal (<130/80 mm Hg) for patients with diabetes or CKD, as both are major risk factors for CVD [5]. Similarly, the American Heart Association/American College of Cardiology recommends a BP goal of $<130 / 80 \mathrm{~mm} \mathrm{Hg}$ for patients at high risk for or with demonstrated coronary artery disease [6]. The American College of Cardiology Foundation/American Heart Association/American Medical AssociationPhysician Consortium for Performance Improvement 2011 Performance Measures for Adults with Coronary Artery Disease and Hypertension report also states that lower BP targets may be appropriate for some patients with coronary artery disease [39].

Despite the evidence supporting the benefit of targeted BP control in high-risk patient groups, some investigators have raised questions regarding incremental benefit with more aggressive BP goals [40-42]. The European Society of Hypertension guidelines note that many recommendations on hypertension management are based on post hoc analyses rather than prospective randomized trial data, with the latter being a preferable evidence base for BP target recommendations in different patient groups [43]. At present, it appears reasonable to adhere to currently established guideline targets and goals of $<130 / 80 \mathrm{~mm} \mathrm{Hg}$ in these high-risk patient groups.
Limitations to the current subgroup and post hoc analyses include that statistical analyses between the subgroups were not completed because of the unequal participant numbers in the subgroups. In addition, the TRINITY study only evaluated the highest doses of each of the 3 agents in the dual- and triple-combination regimens; therefore, it does not provide information on the efficacy and safety of the lower dosing regimens. This study also excluded individuals with illnesses such as symptomatic heart failure and therefore it cannot be determined whether the triple-combination treatment is appropriate for this patient population; caution must be exercised regarding generalizability of these data to the overall population.

\section{Conclusions}

Treatment with OM 40/AML 10/HCTZ 25 mg resulted in greater reductions in SeBP compared with each dualcombination treatment in high-risk subgroups of participants (diabetes, CKD or chronic CVD) from the TRINITY study. Also, a greater proportion of participants in each subgroup achieved BP goal $(<130 / 80 \mathrm{~mm} \mathrm{Hg})$ with the triple combination at week 12 compared with the dual-combination treatments, which was maintained during the open-label period of the study. Long-term triple-combination therapy was well tolerated.

\section{Abbreviations \\ AEs: Adverse events; AML: Amlodipine besylate; ANCOVA: Analysis of covariance; BP: Blood pressure; CKD: Chronic kidney disease; CVD: Cardiovascular disease; ET: Early termination; HCTZ: Hydrochlorothiazide; JNC 7: Seventh report of the joint national committee on prevention, detection, evaluation, and treatment of high blood pressure; LOCF: Last observation carried forward; LS: Least squares; OM: Olmesartan medoxomil; SAE: Serious AE; SE: Standard error; SeDBP: Seated diastolic blood pressure; SeSBP: Seated systolic blood pressure; TEAEs: Treatment-emergent AEs; TRINITY: Triple therapy with olmesartan medoxomil, amlodipine, and hydrochlorothiazide in hypertensive patients study.}

\section{Competing interests}

Dean J. Kereiakes, MD reports no disclosure information. Steven G. Chrysant, $\mathrm{MD}$, has served as a consultant and speakers bureau member for and received grant/research support and honoraria from Daiichi Sankyo Inc. Joseph L. Izzo, Jr., MD, has served as a consultant or investigator for Daiichi Sankyo Inc, Boehringer-Ingelheim, Novartis, GlaxoSmithKline, Takeda Pharmaceuticals, and Forest Laboratories. Michael Melino, PhD, James Lee, PhD, and Victor Fernandez, BS, are employees of Daiichi Sankyo, Inc. Reinilde Heyrman, MD, is a former employee of Daiichi Sankyo, Inc.

\section{Authors' contributions}

The trial was designed by Daiichi Sankyo, Inc. in conjunction with the investigators. All authors contributed to the study design; data analysis/ interpretation; drafting, critical revision, and approval of the manuscript. Medpace, Inc. (Cincinnati, Ohio), a contract research organization, performed project management, data management, clinical and safety monitoring, and statistical analyses in conjunction with Daiichi Sankyo, Inc. The authors are saddened to report the passing in March 2011 of Thomas Littlejohn, III, MD, esteemed physician, investigator, colleague, and co-author of posters and publications from the TRINITY study. His contributions to this manuscript were invaluable. The authors are saddened to report the passing in March 2011 of Thomas Littlejohn, III, MD, esteemed physician, investigator, colleague, and co-author of posters and publications from the TRINITY study. His contributions to this manuscript were invaluable. 


\section{Acknowledgements}

The authors thank Suzanne Oparil, MD, for her critical review of this manuscript. Research funds for this study and preparation of the manuscript were provided by Daiichi Sankyo, Inc, Parsippany, New Jersey. Editorial support for this article was provided by Vrinda Mahajan, PharmD, of Peloton Advantage, LLC, Parsippany, New Jersey. The opinions expressed in the current article are those of the authors. The authors received no honoraria/ fee for service or other form of financial support related to the development of this article.

\section{Author details}

${ }^{1}$ The Christ Hospital Heart and Vascular Center and The Carl and Edyth Lindner Center for Research and Education at the Christ Hospital Cincinnati, $\mathrm{OH}$, USA. ${ }^{2} \mathrm{Oklahoma}$ Cardiovascular and Hypertension Center and University of Oklahoma College of Medicine Oklahoma City, OK, USA. ${ }^{3}$ State University of New York at Buffalo Buffalo, NY, USA. ${ }^{4}$ Piedmont Medical Research Associates Winston-Salem, NC, USA. ${ }^{5}$ Daiichi Sankyo, Inc Parsippany, NJ, USA. ${ }^{6}$ Former employee, Daiichi Sankyo, Inc, Parsippany, NJ, USA.

Received: 27 June 2012 Accepted: 17 October 2012

Published: 30 October 2012

\section{References}

1. Stamler J, Stamler R, Neaton JD: Blood pressure, systolic and diastolic, and cardiovascular risks. US population data. Arch Intern Med 1993 153:598-615.

2. Bakris GL, Sowers JR, Glies TD, Black HR, Izzo JL Jr, Materson BJ, et al: Treatment of hypertension in patients with diabetes-an update. J Am Soc Hypertens 2010, 4:62-67.

3. National Kidney Foundation: KDOQI Clinical Practice Guidelines and Clinical Practice Recommendations for Diabetes and Chronic Kidney Disease. Am J Kidney Dis 2007, 49(2 Suppl 2):S12-S154.

4. Bertoia ML, Waring ME, Gupta PS, Roberts MB, Eaton CB: Implications of new hypertension guidelines in the United States. Hypertension 2011, 58:361-366

5. Chobanian AV, Bakris GL, Black HR, Cushman WC, Green LA, Izzo JL Jr, et al The Seventh Report of the Joint National Committee on Prevention, Detection, Evaluation, and Treatment of High Blood Pressure: the JNC 7 report. JAMA 2003, 289:2560-2572.

6. Rosendorff C, Black HR, Cannon CP, Gersh BJ, Gore J, Izzo JL Jr, et al: Treatment of hypertension in the prevention and management of ischemic heart disease: a scientific statement from the American Heart Association Council for High Blood Pressure Research and the Councils on Clinical Cardiology and Epidemiology and Prevention. Circulation 2007, 115:2761-2788

7. Wong ND, Lopez VA, L'Italien G, Chen R, Kline SE, Franklin SS: Inadequate control of hypertension in US adults with cardiovascular disease comorbidities in 2003-2004. Arch Intern Med 2007, 167:2431-2436.

8. Heidenreich PA, Trogdon JG, Khavjou OA, Butler J, Dracup K, Ezekowitz MD, et al: Forecasting the future of cardiovascular disease in the United States: a policy statement from the American Heart Association. Circulation 2011, 123:933-944.

9. Schmieder RE, Ruilope LM: Blood pressure control in patients with comorbidities. J Clin Hypertens (Greenwich) 2008, 10:624-631.

10. Lewis EJ, Hunsicker LG, Clarke WR, Berl T, Pohl MA, Lewis JB, et al: Renoprotective effect of the angiotensin-receptor antagonist irbesartan in patients with nephropathy due to type 2 diabetes. N Engl J Med 2001, 345:851-860.

11. Brenner BM, Cooper ME, de Zeeuw D, Keane WF, Mitch WE, Parving HH, et al: Effects of losartan on renal and cardiovascular outcomes in patients with type 2 diabetes and nephropathy. N Engl J Med 2001, 345:861-869.

12. Lewis EJ, Hunsicker LG, Bain RP, Rohde RD: The effect of angiotensinconverting-enzyme inhibition on diabetic nephropathy. The Collaborative Study Group. N Engl J Med 1993, 329:1456-1462.

13. Gradman $\mathrm{AH}$ : Rationale for triple-combination therapy for management of high blood pressure. J Clin Hypertens (Greenwich) 2010, 12:869-878.

14. Gradman AH, Basile JN, Carter BL, Bakris GL: Combination therapy in hypertension. J Am Soc Hypertens 2010, 4:42-50

15. Fung V, Huang J, Brand R, Newhouse JP, Hsu J: Hypertension treatment in a Medicare population: adherence and systolic blood pressure control. Clin Ther 2007, 29:972-984.
16. Oparil S, Melino M, Lee J, Fernandez V, Heyrman R: Triple therapy with olmesartan medoxomil, amlodipine besylate, and hydrochlorothiazide in adult patients with hypertension: the TRINITY multicenter, randomized, double-blind, 12-week, parallel-group study. Clin Ther 2010, 32:1252-1269.

17. Kereiakes DJ, Chrysant SG, Izzo JL Jr, Littlejohn TI, Oparil S, Melino M, et al: Long-term efficacy and safety of triple-combination therapy with olmesartan medoxomil, amlodipine besylate, and hydrochlorothiazide for hypertension. J Clin Hypertens 2012, 14:149-157.

18. Weir MR, Hsueh WA, Nesbitt SD, Littlejohn TJI, Graff A, Shojaee A, et al: A titrate-to-goal study of switching patients uncontrolled on antihypertensive monotherapy to fixed-dose combinations of amlodipine and olmesartan medoxomil \pm hydrochlorothiazide. J Clin Hypertens (Greenwich) 2011, 13:404-412.

19. Chrysant SG: Triple-combination therapy with olmesartan, amlodipine, and hydrochlorothiazide in blacks and non-blacks with hypertension: a subgroup analysis of the TRINITY study. Am J CardiovasC Drugs 2012, $12: 233-243$

20. World Medical Association Declaration of Helsink: Ethical principles for medical research involving human subjects. World Medical Association; 2010. http://www.wma.net/en/30publications/10policies/b3/17c.pdf.

21. Jamerson K, Weber MA, Bakris GL, Dahlof B, Pitt B, Shi V, et al: Benazepril plus amlodipine or hydrochlorothiazide for hypertension in high-risk patients. N Engl J Med 2008, 359:2417-2428.

22. Cushman WC, Ford CE, Cutler JA, Margolis KL, Davis BR, Grimm RH, et al: Success and predictors of blood pressure control in diverse North American settings: the antihypertensive and lipid-lowering treatment to prevent heart attack trial (ALLHAT). J Clin Hypertens (Greenwich) 2002, 4:393-404.

23. Bangalore S, Messerli FH, Cohen JD, Bacher PH, Sleight P, Mancia G, et al: Verapamil-sustained release-based treatment strategy is equivalent to atenolol-based treatment strategy at reducing cardiovascular events in patients with prior myocardial infarction: an INternational VErapamil SR-Trandolapril (INVEST) substudy. Am Heart J 2008, 156:241-247.

24. Devereux RB, de Faire U, Fyhrquist F, Harris KE, Ibsen H, Kjeldsen SE, et al: Blood pressure reduction and antihypertensive medication use in the losartan intervention for endpoint reduction in hypertension (LIFE) study in patients with hypertension and left ventricular hypertrophy. Curr Med Res Opin 2007, 23:259-270.

25. Elijovich F, Laffer C: A role for single-pill triple therapy in hypertension. Ther Adv Cardiovasc Dis 2009, 3:231-240.

26. Brixner DI, Jackson KC, Sheng X, Nelson RE, Keskinaslan A: Assessment of adherence, persistence, and costs among valsartan and hydrochlorothiazide retrospective cohorts in free- and fixed-dose combinations. Curr Med Res Opin 2008, 24:2597-2607.

27. Jackson KC, Sheng X, Nelson RE, Keskinaslan A, Brixner DI: Adherence with multiple-combination antihypertensive pharmacotherapies in a US managed care database. Clin Ther 2008, 30:1558-1563.

28. Basile J, Neutel J: Overcoming clinical inertia to achieve blood pressure goals: the role of fixed-dose combination therapy. Ther Adv Cardiovasc Dis 2010, 4:119-127.

29. Calhoun DA: Use of single-pill combination therapy in the evolving paradigm of hypertension management. Expert Opin Pharmacother 2009, 10:1869-1874.

30. Chrysant SG: Using fixed-dose combination therapies to achieve blood pressure goals. Clin Drug Investig 2008, 28:713-734

31. Bangalore S, Kamalakkannan G, Parkar S, Messerli FH: Fixed-dose combinations improve medication compliance: a meta-analysis. Am J Med 2007, 120:713-719.

32. Gupta AK, Arshad S, Poulter NR: Compliance, safety, and effectiveness of fixed-dose combinations of antihypertensive agents: a meta-analysis. Hypertension 2010, 55:399-407.

33. Pittman DG, Tao Z, Chen W, Stettin GD: Antihypertensive medication adherence and subsequent healthcare utilization and costs. Am J Manag Care 2010, 16:568-576.

34. Schmitt KE, Edie CF, Laflam P, Simbartl LA, Thakar CV: Adherence to antihypertensive agents and blood pressure control in chronic kidney disease. Am J Nephrol 2010, 32:541-548.

35. Wald DS, Law M, Morris JK, Bestwick JP, Wald NJ: Combination therapy versus monotherapy in reducing blood pressure: meta-analysis on 11,000 participants from 42 trials. Am J Med 2009, 122:290-300.

36. Law MR, Morris JK, Wald NJ: Use of blood pressure lowering drugs in the prevention of cardiovascular disease: meta-analysis of 147 randomised 
trials in the context of expectations from prospective epidemiological studies. BMJ 2009, 338:b1665.

37. Mancia G, De Backer G, Dominiczak A, Cifkova R, Fagard R, Germano G, et al: 2007 Guidelines for the Management of Arterial Hypertension: The Task Force for the Management of Arterial Hypertension of the European Society of Hypertension (ESH) and of the European Society of Cardiology (ESC). J Hypertens 2007, 25:1105-1187.

38. Mallat SG: What is a preferred angiotensin II receptor blocker-based combination therapy for blood pressure control in hypertensive patients with diabetic and non-diabetic renal impairment? Cardiovasc Diabetol 2012, 11:32.

39. Drozda J Jr, Messer JV, Spertus J, Abramowitz B, Alexander K, Beam CT, et al: ACCF/AHA/AMA-PCPI 2011 performance measures for adults with coronary artery disease and hypertension: a report of the American College of Cardiology Foundation/American Heart Association Task Force on Performance Measures and the American Medical AssociationPhysician Consortium for Performance Improvement. J Am Coll Cardiol 2011, 58:316-336.

40. Cooper-DeHoff RM, Gong Y, Handberg EM, Bavry AA, Denardo SJ, Bakris GL, et al: Tight blood pressure control and cardiovascular outcomes among hypertensive patients with diabetes and coronary artery disease. JAMA 2010, 304:61-68.

41. Cushman WC, Evans GW, Byington RP, Goff DC Jr, Grimm RH Jr, Cutler JA, et al: Effects of intensive blood-pressure control in type 2 diabetes mellitus. N Engl J Med 2010, 362:1575-1585.

42. Patel A, MacMahon S, Chalmers J, Neal B, Woodward M, Billot L et al: Effects of a fixed combination of perindopril and indapamide on macrovascular and microvascular outcomes in patients with type 2 diabetes mellitus (the ADVANCE trial): a randomised controlled trial. Lancet 2007, 370:829-840.

43. Mancia G, Laurent S, Agabiti-Rosei E, Ambrosioni E, Burnier M, Caulfield MJ, et al: Reappraisal of European guidelines on hypertension management: a European Society of Hypertension Task Force document. J Hypertens 2009, 27:2121-2158.

doi:10.1186/1475-2840-11-134

Cite this article as: Kereiakes et al: Olmesartan/amlodipine/

hydrochlorothiazide in participants with hypertension and diabetes, chronic kidney disease, or chronic cardiovascular disease: a subanalysis of the multicenter, randomized, double-blind, parallel-group TRINITY study. Cardiovascular Diabetology 2012 11:134.

\section{Submit your next manuscript to BioMed Central and take full advantage of:}

- Convenient online submission

- Thorough peer review

- No space constraints or color figure charges

- Immediate publication on acceptance

- Inclusion in PubMed, CAS, Scopus and Google Scholar

- Research which is freely available for redistribution 